\title{
Intraoperative iris transillumination in paediatric eyes undergoing cataract surgeries: report of two cases
}

\author{
Sudarshan Khokhar, Amber Amar Bhayana 주, Himani Thakur, Tavishi Singhal
}

Ophthalmology, Dr. Rajendra Prasad Centre for Ophthalmic Sciences, All India Institute of Medical Sciences, New Delhi, India

\section{Correspondence to}

Dr Amber Amar Bhayana; amber.amar.bhayana@gmail. com

Accepted 9 February 2021

\section{DESCRIPTION}

Two children with bilateral congenital cataracts were operated for cataract surgery of one eye each. The first was a 6 months old (preterm delivery at 7 months gestation) with no other apparent ocular pathology (figure $1 \mathrm{~A}-\mathrm{C}$ ); the second was a 10 months old case of Peter's anomaly with buphthalmos (figure 2A,B). The second case had $360^{\circ}$ of posterior synechiae, a poorly dilating pupil, iris bombe, $360^{\circ}$ of anterior synechiae in midperiphery with peripheral iris totally plastered to cornea (figure $2 \mathrm{~B}$ ). Lensectomy was done through a sub iris route in this case. After lens aspiration/ lensectomy and anterior vitrectomy in both cases, posterior segment evaluation was done as a part of routine surgery. ${ }^{1}$ The illuminator was tilted, and the pattern of iris was visualised against the glow of fundus. In the first case, the entire iris was transilluminating, and ciliary processes were visualised (figure 1C). Deficiency of pigments in iris allowed significant transillumination indicating it being an immature iris. In the second case, the iris peripheral to anterior synechiae was atrophic showing transillumination defect, allowing the pattern of iris muscle fibres to be visualised (figure 2C,D).

Transillumination is an examination method in which on slit lamp examination, a co-axial illumination is used through the pupil to illuminate the eye. Transillumination of iris is thus made possible against the glow of the fundus. ${ }^{2}$ This can be used to detect patency of peripheral iridotomies, localised iris thinning, mid-peripheral defects in pigment dispersion syndrome, diagnosing entities like bilateral acute iris transillumination. Transillumination has only been described on slit lamp examination in the literature. This is not possible in paediatric cases where examination on slit lamp is not possible and also in patients with cataracts that obstruct illumination of fundus. We normally use an endoilluminator in all our paediatric cataract surgery cases for intraoperative posterior segment evaluation

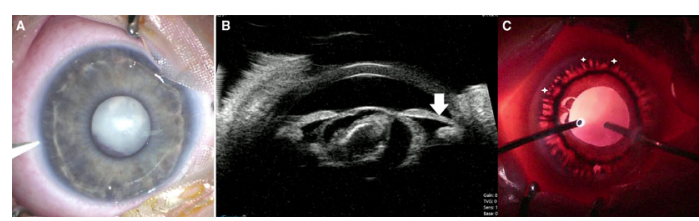

Figure 1 (A) Left eye of a 6-month-old child with congenital cataract; (B) ultrasound biomicroscopy of the same eye showing peripheral iris thinning (white arrow); (C) intraoperative transillumination done with endoilluminator after lens aspiration and anterior vitrectomy showing thin iris with ciliary processes (stars).

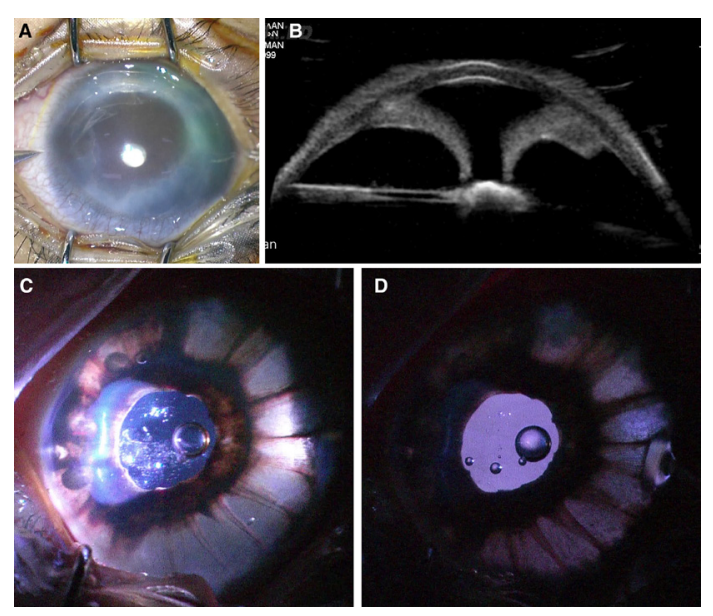

Figure 2 (A) Right eye of 10-month-old child with Peter's anomaly with bupthalmos with cataract; (B) ultrasound biomicroscopy of the same eye showing iris bombe with $360^{\circ}$ anterior synechiae; (C),(D) transillumination as in case 1 with endoilluminator showing thin atrophic see through iris with iris fibre patterns seen.

using wide angle viewing lenses. ${ }^{1}$ While manoeuvring the illuminator, we found that this method can also be used to detect transillumination defects in iris as depicted in our images. In the first case, we could even depict ciliary processes (figure 1C) and in the second case, we could depict iris muscle fibre arrangement (figure 2C,D) as shown. Our method is as good as slit lamp method if not better and can prove really helpful in opportunistically detecting thin/atrophic iris or iris defects in paediatric/adult cases intraoperatively during cataract surgeries.

\section{Learning points}

- Transillumination is a good way to look for iris defects or areas of iris thinning.

- Apart from conventional slit lamp examination, transillumination can also be done intraoperatively after lens extraction (during cataract surgeries) using an endoilluminator.

Acknowledgements Consent has been directly obtained from the patient's father, as ages of children were less than 1 year.

Contributors SK contributed to concept, editing of manuscript. $A A B$ contributed to preparation of manuscript. HT contributed to video editing. TS contributed to video retreival.

Funding The authors have not declared a specific grant for this research from any funding agency in the public, commercial or not-for-profit sectors.

Competing interests None declared. 
Patient consent for publication Consent obtained from parent(s)/guardian(s).

Provenance and peer review Not commissioned; externally peer reviewed.

\section{ORCID iD}

Amber Amar Bhayana http://orcid.org/0000-0002-0770-601X

\section{REFERENCES}

1 Khokhar S, Bhayana AA, Deora A. Technique for posterior segment evaluation in pediatric cases undergoing cataract surgeries. BMJ Case Rep.

2 Abrams JD. Transillumination of the Isis during routine SLIT-LAMP examination. $\mathrm{Br} J$ Ophthalmol 1964;48:42-4.

Copyright 2021 BMJ Publishing Group. All rights reserved. For permission to reuse any of this content visit

https://www.bmj.com/company/products-services/rights-and-licensing/permissions/

BMJ Case Report Fellows may re-use this article for personal use and teaching without any further permission.

Become a Fellow of BMJ Case Reports today and you can:

- Submit as many cases as you like

- Enjoy fast sympathetic peer review and rapid publication of accepted articles

- Access all the published articles

Re-use any of the published material for personal use and teaching without further permission

Customer Service

If you have any further queries about your subscription, please contact our customer services team on +44 (0) 2071111105 or via email at support@bmj.com.

Visit casereports.bmj.com for more articles like this and to become a Fellow 